\title{
A Brief Overview About the Proteins and the Processes Responsible for the Formation of the Nativ-folded Thioproteins in the Pro- and Eukaryotic Cells
}

\author{
J. Kruusma, ${ }^{a}$ A.M. Benham, ${ }^{b}$ J.A.G. Williams, ${ }^{b}$ R. Kataky ${ }^{b, *}$ \\ ${ }^{a}$ Institute of Physical Chemistry, University of Tartu, Jakobi 2, Tartu, 51014, Estonia \\ ${ }^{b}$ The Centre for Bioactive Chemistry, University of Durham, South Road, \\ Durham, DH1 4HT, U.K.
}

Received 15 November 2005

\begin{abstract}
This review was erected to describe briefly proteins and processes responsible for the formation of the nativ-folded thioproteins in the pro- and eukaryotic cells. This issue has a significant importance due to many dieases and misfunctions caused by misfolded enzymes having low or inactive structure.

This review contains also a short list of electrochemical methods for the detection and the quantification of the most important thioproteins.
\end{abstract}

Keywords: thiol proteins, electrochemistry, protein disulfide isomerase, eukaryotic cells.

\section{Introduction}

The prokaryotic and eukaryotic cells differ by inner structure of them. Eukaryotic cells being more sophisticated have inner membranes separating special compartments, like mitochondria, nucleus or the endoplasmic reticulum (ER), having unique functions.

The ER is a compartment where the synthesis of the proteins and enzymes occurs (see Fig. 1). The ER has a network of flattened sacs and branching tubules that extends throughout the cytoplasm of the cells. A single continuous membrane interconnects all these sacs and tubules so that the organelle has only one large, highly convoluted and complexly arranged lumen (internal space). The lumen of this organelle takes often up to more than 10 percent of the total volume of the cell. The membrane of the ER allows molecules to be selectively transferred between the lumen and the cytoplasm, and since it is connected to the double-

\footnotetext{
* Corresponding author. E-mail address: Ritu.kataky@durham.ac.uk.
} 
layered nuclear envelope, it further provides a pipeline between the nucleus and the cytoplasm. Many of the proteins, found in the cisternal space of the endoplasmic reticulum lumen, are there only transiently as they pass on their way to other locations. Other proteins, however, are targeted to constantly remain in the lumen and are known as ER resident proteins. These special proteins, which are necessary for the endoplasmic reticulum to carry out its normal functions, contain a specialised retention signal consisting of a specific sequence of amino acids that enables them to be retained by the organelle.

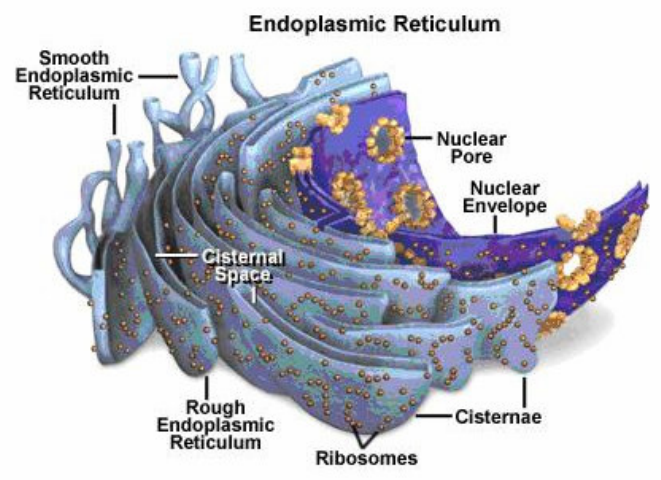

Figure 1. A schematic view on the endoplasmic reticulum. (Reproduced from Ref. [1], with the permission).

The ER can be divided to the rough- and the smooth-looking sections [1]. The rough (granular) endoplasmic reticulum is a system of intracellular membranes looking rough because of multiple ribosome particles attached to them. A part of the rough endoplasmic reticulum is in direct contact with the nuclear membrane. The inner cavity of the rough endoplasmic reticulum is called cisterna. On the membranes of the rough endoplasmic reticulum the proteins destined either for secretion into the intracellular medium or for insertion into the plasma membrane, are synthesised. The secretion of proteins is preceded by a succession of events beginning with transfer of the protein chain having been synthesised on ribosome's, into the inner cavity of the rough endoplasmic reticulum (cisterna). After this the protein is included into the special vesicles and transported into the Golgi complex for further processing and modification. When completed, they are extracted from there into the intracellular fluid [1].

The smooth endoplasmic reticulum is in most cells much less extensive than the rough endoplasmic reticulum and is sometimes alternatively termed transitional. Smooth endoplasmic reticulum is mainly involved in production of lipids, building blocks for carbohydrate metabolism and in the detoxification of harmful substance [1].

The ER is also the place where the quality of the freshly synthesised proteins is controlled [2].

This quality control is achieved through the association of ER chaperones with unfolded or misfolded polypeptide chains. If these proteins fail to assume their 
native structure, they are retained in the ER and targeted for degradation by the proteasome [2].

Recent studies have shown that the redox potential of the ER is ca. $-0.18 \mathrm{~V}$ being slightly more oxidising than in the cytosol $(-0.22$ to $-0.24 \mathrm{~V})$, but slightly less than in the secretory pathway, where the redox potential is -0.17 to $-0.185 \mathrm{~V}$ (when the total concentration of glutathione is assumed to be equal with $8 \mathrm{mM}$ ) [3]. This balance is crucial for the correct folding (for the formation of the disulphide bond in the needed place) of the thioproteins in the ER.

\section{The most important thioproteins in the ER}

\section{a) The glutathione redox buffer (GSH/GSSG)}

The GSH/GSSG (Fig. 2a and 2b) redox couple is a redox regulator ensuring a stable redox buffer in a living cell $[4,5,6,7,8,9]$. Its redox potential is $-0.24 \mathrm{~V}$ $\left(\mathrm{pH}=7.0, \mathrm{~T}=40^{\circ} \mathrm{C}\right)[6,10]$, which is equivalent to the cytosolic redox potential where it is synthesised [6]. (Wunderlich and Glockshuber [11] recommended to use the value $\mathrm{E}^{\circ}=-0.205 \mathrm{~V}$ for practical purposes, although this value is obtained at $30{ }^{\circ} \mathrm{C}$, primarily due to the fact that the redox potentials of other proteins are measured at this temperature despite the discrepancy with normal body temperature). The total concentration of the glutathione in the ER can vary between 1 and $10 \mathrm{mM}$ [6]. While freshly synthesised glutathione is in reduced form, it must be oxidised to enable transport through the phospholipid bilayer into the ER $[12,13,14,15]$ and probably to mitochondria as well $[16,17]$.

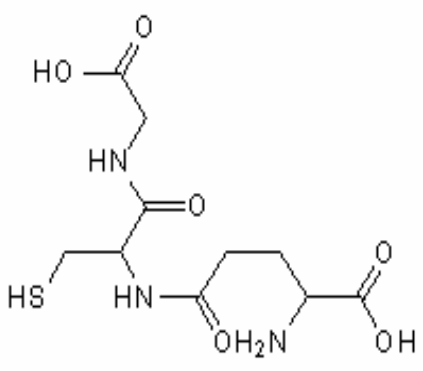

a)

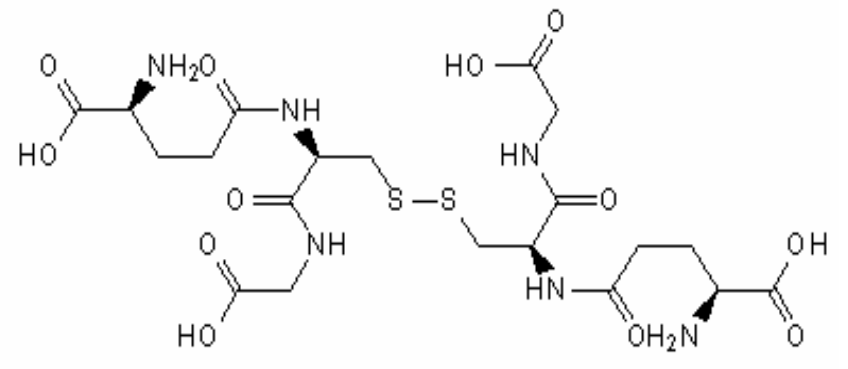

b)

Figure 2. Structures of glutathione, red (a) and glutathione, ox (b).

Redox-buffering in the ER is optimal at the GSH/GSSG concentration ratio 3:1 $[6,18]$ giving a maximal yield of naturally folded proteins. The presence of the protein disulfide isomerase PDI has no significance on the redox buffering [6]. This ratio of the GSH/GSSG keeps the redox potential of the ER at $-0.18 \mathrm{~V}$ [6]. As visible from Fig. $2 a$ and $2 b$, the GSH contains six $\mathrm{pH}$-active functional groups: one of them is thiolic. In the $0.1 \mathrm{M}$ aqueous solution of $\mathrm{KCl}$ background, the $\mathrm{pK}_{\mathrm{a}}$ of thiolic group of GSH is reported as 8.41 [19] (8.7 [20]). The oxidised form of glutathione has only ten ionise able groups (six amine and four carboxylic). 


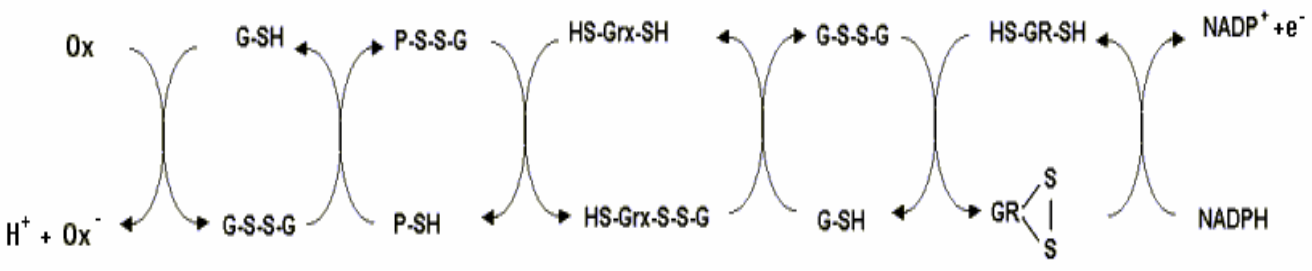

Figure 3. GSH-Grx system: the monothiol pathway catalysing reduction of GSHcontaining mixed disulphides.

The mechanism of buffering by the GSH/GSSG system is complex (Fig. 3). Glutathione acts as both: as an oxidizing agent for proteins and then as a reducing agent of glutaredoxin $\left(\mathrm{Grx}, \mathrm{E}^{\circ}=-0.23 \mathrm{~V}\right.$ [42]). The oxidized glutathione GSSG, is reduced by glutathione reductase (GR). Biochemical studies have discovered the existence of three glutaredoxins: Grx1, Grx2 and Grx3 [10]. Although having differences in the amino acid sequence, they all have very similar secondary structure elements and general fold. Despite of ability of Grx to mimic Trx in the reducing action of dithiols, it is highly selective for the degluta-thionylation of the glutathione containing mixed disulfides [4,21,22,23]. The Grx1 and Grx3 of Esch coli contain identical active sites: -Cys-Pro-Y-Cyshaving the redox potentials -0.233 and $-0.198 \mathrm{~V}$, respectively [10]. The $\mathrm{pK}_{\mathrm{a}}$ for the redox-active cysteine in Gxr is 3.5 [24].

Glutathione is a very general redox switch involved almost in every part of the living organism $[4,5,6,7,8,9,10,12,13,14,15,16,17,25,26]$.

\section{b) Cysteine/cystine redox couple (CSH/CSSC)}

The cysteine/cystine (Fig. $4 \mathrm{a}$ and $4 \mathrm{~b}$ ) redox couple is an ubiquitous buffering redox system [7,27]. It is a typical component of thiol containing proteins, amino acids and protein refolding agents such as thioredoxin and protein disulphide isomerase (PDI). The redox potential of cysteine is reported as $-0.22 \mathrm{~V}$ (measured from the equilibrium between $\mathrm{GSH}$ and $\mathrm{CSH}$ at the $\mathrm{pH} 7, \mathrm{~T}=37{ }^{\circ} \mathrm{C}$ and in $0.1 \mathrm{M}$ phosphate buffer) [28].

This implies that, in the cell, the oxidised form is normally as the free form [29]. Cysteine contains three $\mathrm{pH}$-active functional groups. In a $0.1 \mathrm{M} \mathrm{KCl}$ aqueous background, the $\mathrm{pK}_{\mathrm{a}}$ of this group is 8.13 [30] (8.3 [20]). Oxidised form of the cysteine (cystine) has four ionisable groups (two amino and two carboxylic). 


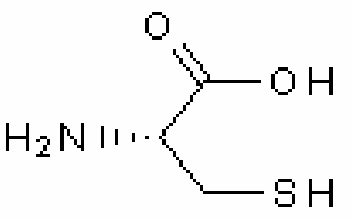

a)

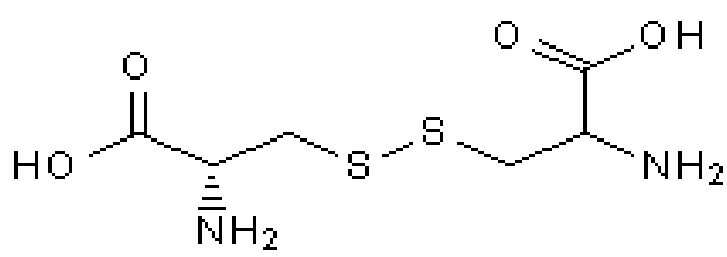

b)

Figure 4. Structures of cysteine (a) and cystine (b).

The redox modulation of the cysteine containing proteins leads to the formation of intra- and intermolecular disulphide bonds. Very often these intermolecular disulphide bonds will form with glutathione. These changes activate or inactivate proteins due to conformational changes or altering protein-binding site(s). It has been suggested, that in the presence of oxygen or oxidising agents (i.e. oxidative stress), these highly redox sensitive cysteines can oxidise to cysteine sulfenic (Cys-SOH) or even to cysteine sulfinic acids $\left(-\mathrm{Cys}-\mathrm{SO}_{2} \mathrm{H}\right)[31,32]$.

Some thioproteins contain certain cysteine fractions where sulfur is replaced by selenium (marked as SeCys) [4,32,33]. This kind of thioredoxin reductases (TrxR's), having an active center sequence-Gly-Cys-SeCys-Gly-, are found in the cells of mammals [34,35] and the nematode worm Caenorhabdits elegans $[36,37]$.

The redox status of sulfur in the cysteine groups of the proteins inside a cell is mainly controlled by the thioredoxin and the GSH/GSSG redox system through thiol/dithiol equilibrium utilising NADPH as a cofactor for the regeneration of these systems [4].

\section{c) Thioredoxin (Trx)}

Thioredoxin is a member of the thiol-disulphide oxidoreductases family. It is a protein (molecular mass $12 \mathrm{kDa}$ ) with a redox-active dithiol in the active site Cys-Gly-Pro-Cys- and constitutes a major thiol reducing system (the so-called thioredoxin system) [38,39]. The thiol group of the first N-terminal Cys residue of the-Cys-Gly-Pro-Cys- active site is important for the bioactivity of Trx [39]. In the cytoplasm of prokaryotic and eukaryotic cells thioredoxin is involved in the protein degradation [40] and the activity regulation [39] processes. Thioredoxin plays with GSH key roles in the regulation of apoptosis ("cell suicide"), cell cycle and growth control by thiol reduction. Thioredoxin system contains many related molecules interacting with each other through the active sites of cysteine residues. Thioredoxin couples with thioredoxin dependent peroxidases to neutralise hydrogen peroxide and to reduce the oxidative stress in a cell [41]. Thioredoxin family has many members having higher molecular mass than thioredoxin itself. They also have a different composition in their -Cys-X$X^{\prime}$-Cys- motif ( $X$ and $X^{\prime}$ marking residues of different amino acids) [42]. The redox potential of Trx depends upon the source of origin while the $X$ and $X^{\prime}$ are 
variable. In general, the redox potential of the cytosolic Trx is close to $-0.26 \mathrm{~V}$ [43]. This motif can be as highly reducing $\left(\mathrm{E}^{\circ}=-0.27 \mathrm{~V}\right.$, in the $\operatorname{Trx}$ in E. coli), intermediate (PDI, $\mathrm{E}^{\circ}=-0.18 \mathrm{~V}$ ) or even oxidising (DsbA of the E. coli, $\mathrm{E}^{\circ}=-0.09$ to $-0.11 \mathrm{~V})[42,44,45,46,47,48]$. The $\mathrm{pK}_{\mathrm{a}}$ of the nucleophilic (redox-active) cysteine's -SH group is in the range 6.7-7.4 [24].
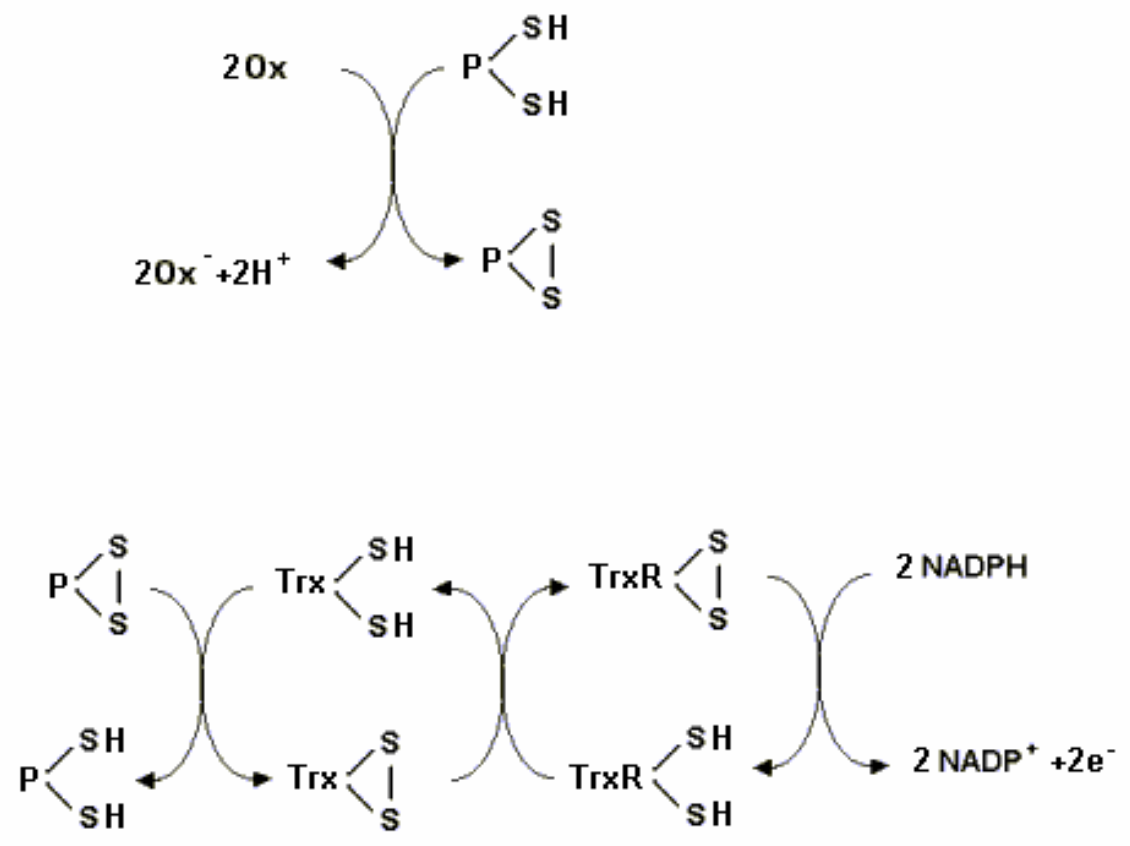

Figure 5. Thioredoxin system. ROS-induced intra- or intermolecular disulphide bonds of the target proteins are reduced by the reduced Trx, which is regenerated by the TrxR coupled with NADPH.

The redox-buffering scheme of Trx (Fig. 5), illustrates the reduction of disulfide bonds in a protein by a Trx causing its unfolding (preceding to the proteins refolding or to degradation). The TrxR, coupled with NADPH co-factor, is involved as an electron and proton donor reducing the oxidised Trx. The electrons are transferred from nicotinamide adenine dinucleotide phosphate (NADPH) to TrxR via flavin adenine dinucleotide (FAD) [4]. The TrxR itself is a dimeric flavoenzyme containing a redox-active disulfide and a FAD unit in the each monomer. It is also a member of the pyridine nucleotide-disulphide oxidoreductase family [49]. Although the bacterial TrxR is highly specific to Trx, the mammalian TrxR has many substrates (Trx included). This may be explained by the presence of the SeCys residue found in the cells of mammals [33,50,51] and the nematode worm Caenorhabdits elegans [52]. This SeCys residue is located at the penultimate carboxyl terminus being the centre of enzymatic activity [49]. It has been postulated [53], that the catalytic power of selenium is used to increase the turnover rates to prevent unspecific chemical reactions. The content of selenium in the TrxR depends directly upon concentration of Se ions in the medium. Despite of being an essential bioelement [33,54], higher 
concentrations of selenite (over $10 \mu \mathrm{M}$ ) will inhibit the reaction of the ribonucleotide reductase and cause general reduction of disulphide bonds in thioproteins $[8,55]$. However, the lack of selenium in the body may cause an increased sensitivity to infectious, cardiovascular, male fertility and to other diseases $[33,54]$.

\section{d) Protein disulfide isomerase (PDI) of the eukaryotic cells}

Disulphide bond formation in the ER of the eukaryotic cells is mediated by at least two types of proteins. In general, the Protein Disulphide Isomerases (PDI) catalyse directly the formation of the disulphide bonds in substrate proteins. The PDI is re-oxidised by hEro proteins. PDI has a dual functionality: first as a redox enzyme and second as an isomerase $[56,57,58,86]$. PDIs contain two redox active thioredoxin-like domains with the active-site sequence: Cys-Gly-His-Cys (presented in the literature as a scheme -C-X-X'-C-) [47,59] (recent studies have indicated also the presence of an eukaryotic PDI having a Ser-X-X'-Cys motif and called as PDILT [60]). The molecular mass of PDIp is $55 \mathrm{kDa}$ [59] and 57 $\mathrm{kDa}$ for PDIR [47,59]. The PDI takes ca. $2 \%$ of the amount of proteins in the ER [61]. The $\mathrm{pK}_{\mathrm{a}}$ value of the isomerisation-active cysteine's thiol group is about 6.7 $[20,62]$.

An investigation of the -Cys-Gly-His-Cys- amino acid sequence of the yeast PDI showed that the sequence contains two homologous active sites (a and a'), two homologous binding domains ( $\mathrm{b}$ and $\mathrm{b}$ '), one highly acidic C-terminal domain (c) and one C-terminal ER-retention signal (KDEL for mammals and HDEL for yeast) $[47,63]$. It is presumed, that the catalytic isomerisation activity of the PDI is due to the participation of two cysteine thiols in the -Cys-Gly-HisCys- active sites, which are operating independently [63]. The redox potential of the mammalian PDI is ca. $-0.11 \mathrm{~V}$ [64]. Disulphide bond formation between cysteine residues, mediated by PDI, occurs probably via transition complex between an oxidised non-native protein and a reduced PDI. This transition complex has two possibilities: the PDI will be oxidised and one of non-native disulphide bonds of the protein cleaved (reduced) or an intermediate complex will be stabilised via isomerisation and the non-native protein folded correctly. If the redox potential of the ER is correct, then after the isomerisation of the protein, the PDI leaves the complex in initial reduced stage and the re-folded protein remains oxidised ready for secretion to the Golgi complex [65]. The reduced PDI is believed to be oxidised by a special redox-mediator Erolp [66].

\section{e) Endoplasmatic retikulum oxidase (Ero)}

Erolp is a membrane-associated iron-sulphur protein [18,57,67] with the molecular mass $65 \mathrm{kDa}$ [67]. This enzyme is responsible for the re-oxidation of the PDI in the prokaryotic cells $[9,57,67,68,69,70,71]$. It is a single domain protein having a $\alpha$-helical structure with five short $\beta$-sheets and two extended loops [57]. Seven conserved cysteine residues of Erolp have fixed functions: Cys352 and Cys355 keep it in a completely oxidised form, Cys100 and Cys 105 are probably interacting with PDI. Cys352 and Cys355, Cys100 and Cys105, and 
Cys90 and Cys349 are paired with each other leaving the Cys208 alone in thiol form. It seems that the initial source of oxidising source for eukaryotes and for prokaryotes is molecular oxygen via the cofactor FAD tightly bound with Erolp $[57,70]$. Frand and Kaiser have proposed a scheme where electrons are initially transferred from PDI to Cys100-Cys105, and then inside Ero1p to the couple Cys352-Cys355 before donating them to the FAD [72]. The mechanism of the electron transfer between molecular oxygen and FAD cofactor, locating inside Erolp's structure, is not known. It can exist a still not discovered electrontransporter between molecular oxygen and the Ero1p [57].

Second enzyme, a membrane-associated flavoproteine, able to oxidise the PDI in a cell, is Erv2p [57]. Erv2p is structurally related to QSOX family of the sulfhydryl oxidases, which also use FAD to oxidise PDI. The mechanism of this enzymatic process is similar to Ero1p one's [57,73]. Erv2p is a small (molecular mass $22 \mathrm{kDa}$ ) [69] mostly $\alpha$-helical dimer. As in Erolp, the FAD is tightly bound within the structure of Erv2p adjacent to the -Cys-Gly-Glu-Cys- motif [74]. The second cysteine pair (-Cys-Gly-Cys-) is located in the flexible loop, while the mobile pair of cysteine is placed in the sub unit opposite to the -CysGly-Glu-Cys- motif [57]. Despite of similarities of the tertiary structures of Ero1p and Erv2p, their molecular sequence is different (as their molecular masses). In addition, the Erv2p contains a short hydrophobic channel with the correct size to enable the molecular oxygen to diffuse to the active site of the cofactor FAD [75].

\section{f) Protein disulfide isomerases (Dsb's) of the prokaryotic cells}

Dsb's are natural folding and refolding agents of proteins in the periplasm (locating between cytoplasmic and outer membrane) of prokaryotic cells $[56,76]$. There are six types of bacterial protein disulphide isomerases marked as DsbA, DsbB, DsbC, DsbD, DsbE and DsbG [76,77]. The DsbA consists of 189 residues, two of them cysteines able to form disulphide bonds. They have similar active site structures as eukaryotic PDI's with a redox potential $(-0.089 \mathrm{~V}, \mathrm{pH}=7$, $\mathrm{T}=30{ }^{\circ} \mathrm{C}$ ) [11]. DsbA is $21 \mathrm{kDa}$ water-soluble protein which is responsible for disulphide formation in the bacterial periplasm $[11,66,76,78]$. Because of the relatively high redox potential and low pKa (ca. $3.5[11,24])$ of the nucleophilic cysteine residues, it is unable to refold non-native disulphide bonds to native ones. DsbC assists DsbA to re-fold proteins [77].

DsbB is a directly interacting reoxidising protein of DsbA. It is a cytoplasmperiplasm separating membrane bound redox protein having two redox-active cysteine groups oriented into periplasm $\left(\mathrm{E}^{\circ}=-0.069 \mathrm{~V}\right.$ and $-0.186 \mathrm{~V}$ [77]). The molecular weight of DsbB is ca. $20 \mathrm{kDa}$. It probably has four transmembrane helices and two periplasm locating cysteine (four residues) containing loops. DsbB is confirmed to be oxidised by quinones ( $\mathrm{E}^{\circ}$ for ubiquinone is $+0.11 \mathrm{~V}$ [79] and for menaquinone $-0.067 \mathrm{~V}[80]$ ) and the quinones via terminal cytochrome molecular oxygen [77,79].

The DsbC, DsbE and DsbG are the catalysts of the disulphide bond isomerisation $[77,79]$ with DsbC identified as the main isomerisation catalyst. The exact function of the other Dsb's is not yet well known. 


\section{g) Small synthetic disulphide bond isomerases (SSTP)}

Mimics of the natural PDI have been designed to probe thiol-dithiol bond formation and to enhance laboratory synthesis of natural enzymes and medicines. The main requirements for effective protein folding and refolding for SSTP are the redox potential near $-0.18 \mathrm{~V}$ and thiol $\mathrm{pK}_{\mathrm{a}}$ close to 7 [81].

Three types of thiols have been studied:

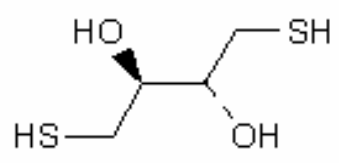

Figure 6. Structure of dithiothreitol (DTT).

a) Monothiols

1) Dithiothreitol (DTT, Fig. 6), the $\mathrm{E}^{\circ}=-0.323 \mathrm{~V}$ [82] and $\mathrm{pK}_{\mathrm{a}} 9.3$ and 10.6 [83]. This compound if often used as a reductant of disulphide bonds due to a low standard potential;

2) $\mathrm{N}$-methylmercaptoacetamide, (Fig. 7) has a $\mathrm{pK}_{\mathrm{a}}=8.3$ [86], the redox potential is unknown;

3) 4-mercaptobenzeneacetate (monothiolic compound, Fig. 8), $\mathrm{pK}_{\mathrm{a}}=6.6$ [20], $\mathrm{E}^{\circ}$ in unknown;

4) 2-mercaptoethanol (Fig. 9) $\left(\mathrm{pK}_{\mathrm{a}}=9.6\right)$ [84] is a commonly used disulphide bonds cleaving agent.<smiles>CSNC(C)=O</smiles>

Figure 7. Structure of N-methylmercaptoacetamide.<smiles>O=C(O)Cc1ccc(S)cc1</smiles>

Figure 8. Structure of 4-mercaptobenzacetate.<smiles>OCCS</smiles>

Figure 9. Structure of 2-mercaptoethanol. 
b) Dithiols

1) Cys-Gly-Cys (CGC) (dithiolic compound, Fig. 10), $\mathrm{E}^{\circ}=-0.167 \mathrm{~V}$ and $\mathrm{pK}_{\mathrm{a}}=$ $8.7[81]$

2) CGC Trx (dithiolic compound, Fig. 11), $\mathrm{E}^{\circ}=-0.2 \mathrm{~V}$ and $\mathrm{pK}_{\mathrm{a}}$ unknown [81];

3) Cys-Gly-Pro-Cys-Trx (CGPC Trx) (dithiolic compound, Fig. 12), $E^{\circ}=-0.270$ and $\mathrm{pK}_{\mathrm{a}}=7.5[81]$;

4) (士)-trans-1,2-bis(mercaptoacetamido)cyclohexane (BMC) (dithiolic compound, Fig. 13) [85,86] with molecular mass $262 \mathrm{Da}$ [86]. Its thiols $\mathrm{pK}_{\mathrm{a}}$ 's are 8.3 and 9.9 and $\mathrm{E}^{\circ}=-0.24 \mathrm{~V}[86]$.

c) Trithiols

1) Tris(2-mercaptoacetamidoethyl)amine (a symmetric trithiolic compound, Fig. 14), $\mathrm{E}^{\circ}=-0.208 \mathrm{~V}$ and $\mathrm{pK}_{\mathrm{a}}=8.3[87]$;

2) 2-carboxyethylphosphine (TCEP) (Fig. 15). The ability of trialkylphosphine compounds to reduce protein disulphide bonds has been known for many years. Trialkylphosphines selectively reduce disulfide bonds, and are essentially nonreactive toward other functional groups commonly present in proteins. Trialkylphosphines, however, were hindered by their instability in water and their disagreeable odour. These obstacles were overcome by the discovery of tris(2-carboxyethyl)phosphine (TCEP), a popular odourless reducing agent for protein applications $[88,89]$.

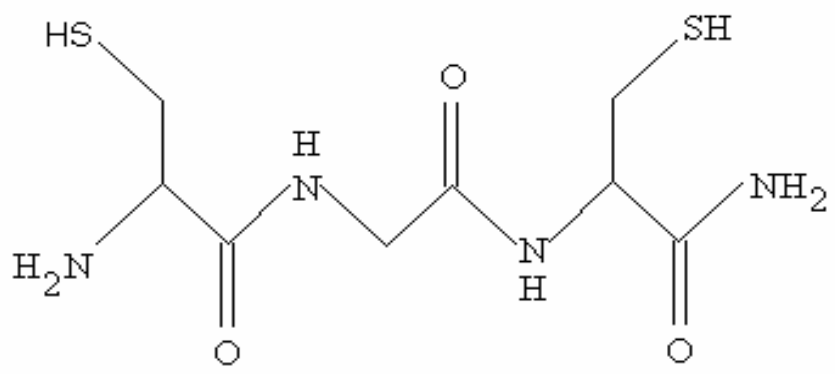

Figure 10. Structure of Cys-Gly-Cys.

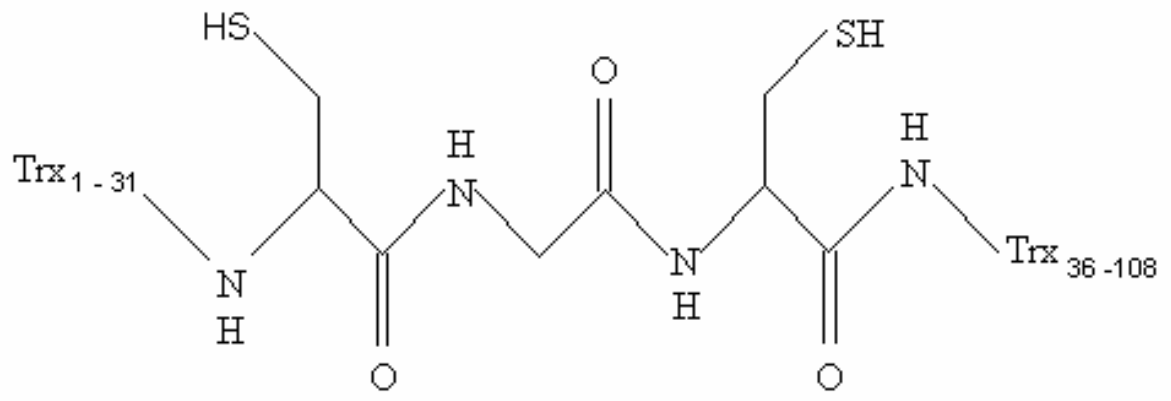

Figure 11. Structure of Cys-Gly-Cys Trx. 
Dithiols, like BMC, are more efficient than monothiols due to their ability to form cyclic disulphides and therefore forming more labile mixed disulphides increasing the turnover rates and yields of natively folded proteins $[85,86,87]$.

Trithiolic compounds have been successfully applied as synthetic refolding agents after their immobilisation on the solid surfaces by a - SH group leaving the two other thiol groups actived [87].

Aromatic PDI mimics are also quite effective refolding agents (compared to their aliphatic relatives) due to their low $\mathrm{pK}_{\mathrm{a}}$ values of their thiols $\left(\mathrm{pK}_{\mathrm{a}} 3-7\right)$. The closest aromatic thiol to PDI is the 4-mercaptobenzeneacetate (Fig. 8) having a thiolic $\mathrm{pK}_{\mathrm{a}} 6.6$ and being able to fold RNase $\mathrm{A}$ at the rate 5 to 6 times faster than glutathione [81].

The semi-synthetic CGC Trx peptide sequence is the closest reported PDI mimic and is more efficient folding agent compared to BMC (folding activity of RNase $3300 \mathrm{U} / \mathrm{mol}$ compared to $56 \mathrm{U} / \mathrm{mol}$ for BMC). This linear CGC Trx is the most efficient synthetic disulphide bond refolding catalyst due to its favourable redox properties and the existence of the linear-Cys-X-Cys- motif [81].

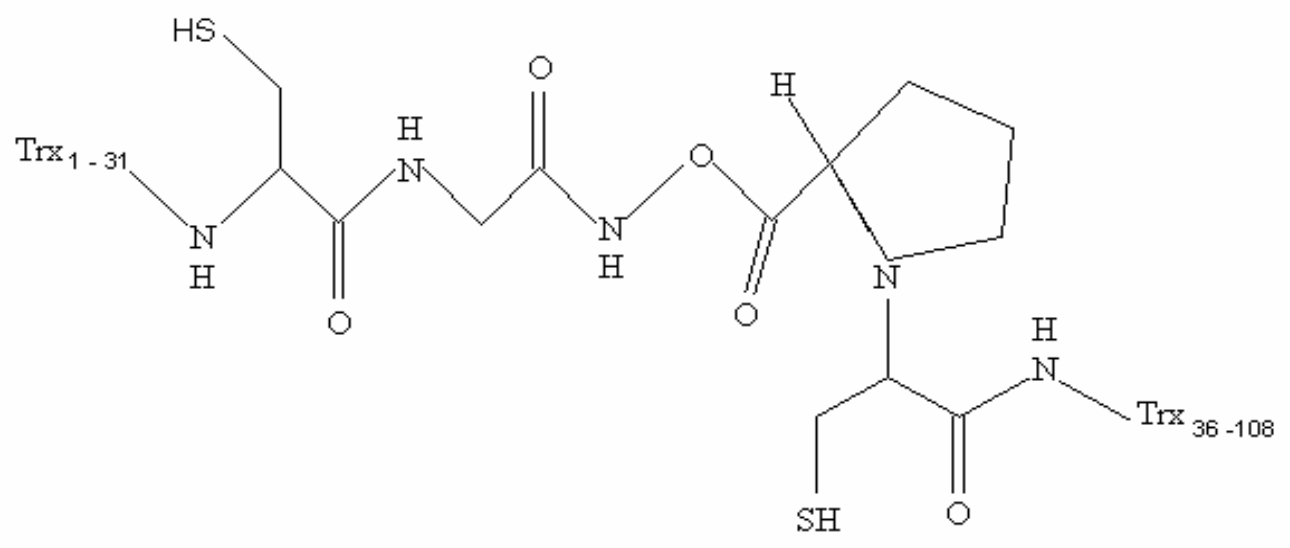

Figure 12. Structure of Cys-Gly-Pro-Cys Trx.

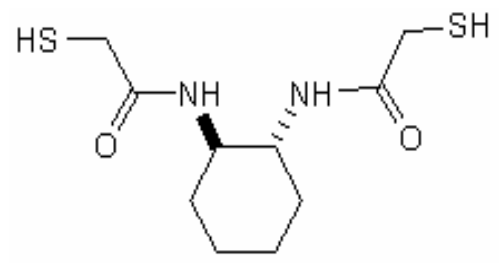

Figure 13. Structure of ( \pm )-trans-1,2-bis(mercaptoacetamido)cyclohexane (BMC).<smiles>CC(C)CCNC(=O)CSCC(C)(C)C</smiles>

Figure 14. Structure of tris(2-mercaptoacetamidoethyl)amine. 
These small synthetic dithiol-containing molecules can behave as isomerases, but their bioactivities are still much less than of natural PDI. A natural PDI is 7 up to 12 fold more efficient folding agent of RNase A compared to BMC or CGC. Nevertheless these mimics are useful because they can provide better options for native disulphide formation, heterogeneous protein expression and purification from inclusion bodies, and may be very useful in chemotherapy [81].

\section{Electrochemical methods for the determination of the thiol-containing peptides}

The electrochemical methods for the detection of the thiol-containing substances are welcome due to their low cost of the analytical detection and the simplicity of the analysis. A direct voltammetric or an amperometric, after a capillary or a HPLC column separation, determination of the thiols have been developed. When using the voltammetric methods, the potential applied between a working and a counter electrode is changed in monotonous way to one direction. Due to the electrochemical reaction of the analyte, the measured Faraday current is proportional to the concentration of the analyzed substance. The electrochemical reaction starts when the potential of the working electrode crosses the redox potential of the compound being studied. While the redox potential is specific for different electro-active compounds, therefore it is possible to distinguish them and to analyze individual substances. The obtained potential-current relationship is called as the voltammogram.

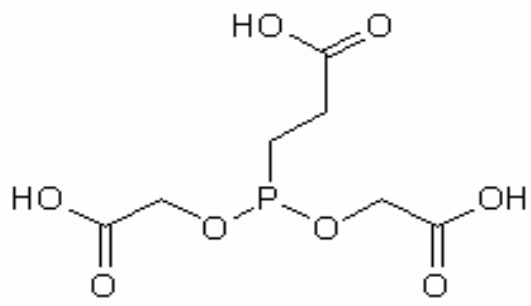

Figure 15. Structure of 2-carboxyethylphosphine (TCEP).

An alternative method to analyze individual thiols (and other substances) is to use physical-chemical ways of special separation like chromatography or electrophoresis. When individual compounds are physically separated from each other there is no more need for sophisticated detection. Instead of potential sweep, as used in the stripping voltammetry, the potential of the working electrode is fixed, so that the compound wanted to analyze will oxidize or reduce giving the Faraday current of an electrochemical reaction. This current is measured and its value is proportional with the concentration of the studied compound in the solution analyzed.

The concentration of the analyte in the sample is normally measured by the so-called standard addition method using the obtained calibration graph. 


\section{Voltammetric detection methods}

\section{a) Direct voltammetric measurements}

1) Christine et al. [90] used a cathodic stripping voltammetry (CSV) to analyse glutathione content in the Atlantic ocean at nanomolar levels using a Hanging Mercury Drop Electrode, a $\mathrm{Ag} / \mathrm{AgCl}$ reference electrode and a $\mathrm{Pt}$ counter electrode. It was observed a stripping peak of glutathione due to the appeared at a potential ca. $-0.55 \mathrm{~V}$ vs. $\mathrm{Ag} / \mathrm{AgCl}$ (in $3 \mathrm{M} \mathrm{KCl}$ aq.) [91]. One single analysis lasted approximately 30 minutes. The relative standard deviation of the analyses of the glutathione was $14 \%$.

2) A direct determination of homocysteine, $\mathrm{N}$-acetylcysteine, cysteine and glutathione was performed using an edge plane pyrolytic electrode [92]. A clear oxidation peak of $80 \mu \mathrm{M}$ homocysteine and a tiny reduction one were observed when cyclic voltammograms at the scan rate $55 \mathrm{mV}$ were performed. In the same conditions the basal plane pyrolytic graphite, glassy carbon, boron-doped diamond and carbon nanotube "film" modified basal plane pyrolytic electrodes did not give a detectable analytical signal. The limits of detection using the edge plane pyrolytic electrode were: homocysteine $-2.1 \mu \mathrm{M}, \mathrm{N}$-acetylcysteine -1.7 $\mu \mathrm{M}$, cysteine $-2.6 \mu \mathrm{M}$ and glutathione $-2.7 \mu \mathrm{M}$.

3) The ferrocene-modified $(1 \% \mathrm{w} / \mathrm{w})$ carbon paste electrode (redox-mediator blended with graphite powder-(high viscosity)paraffin oil paste) was used for direct electrochemical differential pulse voltammetric determination of cysteine [93]. The optimal media for the determination was $0.1 \mathrm{M}$ phosphate buffer $(\mathrm{pH}=$ 7.00). The detection limit for cysteine was $4.7 \mu \mathrm{M}(2 \sigma)$ and linear range of the electrochemical signal from $8.9 \mu \mathrm{M}$ to $0.2 \mathrm{mM}$.

4) A platinum / carbon nanotube electrode was used as a working electrode for the detection of cysteine [94]. Platinum was electrodeposited onto activated carbon nanotube electrode by electroreduction of previously electrogenerated $\mathrm{Pt}^{4+}$ ions. This electrode gave a linear response to cysteine concentration in the range of $0.5 \mu \mathrm{M}$ to $0.1 \mathrm{mM}$ with a detection limit $0.3 \mu \mathrm{M}(3 \sigma)$.

5) A very sensitive electroanalytical method for the determination of cysteine in the presence $\mathrm{Cu}^{2+}$ ions was developed by Dursun et al. [95]. The reduction peaks of the cysteine complexes of $\mathrm{Cu}^{+}$and $\mathrm{Cu}^{2+}$ ions appear at $\mathrm{E}=-0.60$ and $-0.30 \mathrm{~V}$ vs. SCE, respectively. The calibration curve was linear in the range $0.5 \mathrm{nM}$ until $20 \mathrm{nM}\left(0.1 \mathrm{M} \mathrm{KNO}_{3}, \mathrm{pH}=9.20\right)$. In the "flow trough" technique at the rate 1.5 $\mathrm{mL} / \mathrm{min}$ the calibration graph was linear from $1.0 \mathrm{nM}$ to $100 \mathrm{nM}$ (with a RSD = $1.0 \%$ at the conc. $50 \mathrm{nM}$ cysteine). The detection limit was found to be $0.5 \mathrm{nM}$ $(3 \sigma)$.

\section{b) Voltammetric electroanalytical methods where redox mediators are used}

1) White et al. [96] have reported a method for monitoring thiols using electrochemically initiated 1,4 additions using an ordinary glassy carbon electrode. Many mediators were investigated. This detection methodology relies upon the electro-oxidation of the indicator species to the corresponding quinoid intermediate. The last one reacts with a thiol producing the reduct adduct species. The re-oxidation of the adduct gives an oxidative current, which is directly related to the concentration of the thiols. The lowest limit of detection of cysteine 
$(4 \mathrm{mM})$ was observed when hydroquinone-sulphonic acid $\left(\mathrm{E}^{\circ}=0.187 \mathrm{~V}\right)$ was used.

2) Nekrassova et al. [109] applied octacyanomolybdate(IV) as a mediator for the detection of thiols. An electrocatalytic process occurs, when electro-generated octacyanomolybdate (V) is reduced by thiol to octacyanomolybdate(IV) giving a quantitative electroanalytical response. The electrocatalytic oxidation of cysteine by electro-generated octacyanomolybdate $(\mathrm{V})$ was explored in alkaline solutions. The detection limit on the BDDE for the cysteine was $0.3 \mu \mathrm{M}$.

3) An electrochemical oxidation of catechol as an indicator for the determination of cysteine on the glassy carbon electrode was developed by White et al. [97,98]. Linear range of detection was observed in the concentration range from 2 to 20 $\mu \mathrm{M}$ when the square wave voltammetry was applied. The limit of detection 0.94 $\mu \mathrm{M}$ for glutathione with linear range $1-80 \mu \mathrm{M}$ was observed in the study of Seymour et al. [99].

4) An electroanalytical determination of cysteine using quinones as the redox mediators was explored by Hignett et al. [100]. Using a square wave voltammetry and a glassy carbon electrode the electrochemical response was linear from 5 to $47 \mu \mathrm{M}$.

\section{Amperometric sensors}

\section{a) Amperometric sensors used after-column separation}

1) Terashima et al. [101] and Chailapakul et al. [102] have used a boron-doped diamond electrode after a HPLC column amperometric separation for the detection of oxidised and reduced glutathione and homocysteine. The analysis of GSH and GSSG was done in the Gritton-Robinson buffer at $\mathrm{pH} 2$. The glutathione was detected in an aqueous acidic media $(\mathrm{pH} 2)$ containing $2 \%$ acetonitrile in $0.05 \mathrm{M}$ phosphate buffer. The detection limits were $1.4 \mathrm{nM}$ for GSH, $1.9 \mathrm{nM}$ for GSSG and $1 \mathrm{nM}$ for homocysteine.

2) Simultaneous detection of thiols and disulphides after the separation by a capillary electrophoresis was performed using a mixed-valence ruthenium cyanide-modified carbon fibre array microelectrode [103]. Detection limits were for glutathione disulphide $-2.5 \mathrm{fmol}$, cystine $-1.3 \mathrm{fmol}$ and homocystine 1.1 fmol. The analytical response was linear for cystine over two orders of magnitude. The selective detection of thiols was proved by the analysis of urine of a patient having kidney stones.

3) A selective detection of thiols after capillary electrophoresis using mercury coated gold amalgam microelectrode was developed by O'Shea et al. [104]. The detection bases on the catalytic oxydation of mercury in the presence of thiols. The detection limit for glutathione was $0.53 \mathrm{fmol}(21 \mathrm{nM})$. The RSD of an analysis was $2.1 \%$.

4) Cox and Dabek-Zlotorznska have developed a Ru(III and IV) oxide-cyanocross-links stabilised carbon electrode for the amperometric detection of sulphur containing amino acids and related compounds [105]. The substances being analysed are firstly separated by HPLC. Detection limits are studied for cystine, cysteine, glutathione, methionine and glutathione disulphide. They are in the range from 0.2 to $0.6 \mu \mathrm{M}$. Analytical measurements of the concentrations of these 
compounds can be done between 1 and $50 \mu \mathrm{M}$. The modified electrode is stable 11 days when stored in a citrate-phosphate $(\mathrm{pH}=1)$ mobile phase of the HPLC.

5) Platinum particles-modified electrode for HPLC with pulsed amperometric detection of thiols in rat striatum for an electrocatalytic oxidation of cysteine (Cys), glutathione (reduced form, GSH) and penicilamine (PEN) has been developed showing linear response of peak currents of Cys, GSH and PEN on their concentrations, with the calculated detection limit of $1.1 \times 10^{-7}, 1.8 \times 10^{-7}$ and $3.8 \times 10^{-7} \mathrm{M}$, respectively, by the signal-noise ratio 3 [106].

6) Integrated voltammetric detection (IVD) for thiols using liquid chromatography has been proposed [107]. Determination of thiols by IVD on the gold electrode in the acidic media did show smaller background currents and increased sensitivity compared to pulsed amperometric detection. Using one second long pre-adsorption time onto the electrode, the limit of detection for cysteine was ca. $6 \mathrm{nM}$ per sample amount $50 \mu \mathrm{L}$ (ca. $300 \mathrm{fmol}$ ).

7) The amperometric determination of glutathione and cysteine was reached using a $\mathrm{Pd}-\mathrm{IrO}_{2}$ modified glassy carbon electrode after a HPLC in rat brain microdialysate [108]. The peak currents were linear in the concentration range 10 to $800 \mu \mathrm{M}$ for GSH and 4 to $200 \mu \mathrm{M}$ for Cys. The detection limits were $2 \mu \mathrm{M}$ for GSH and $0.5 \mu \mathrm{M}$ for Cys. The effluent was $0.1 \mathrm{M}$ aqueous phosphate buffer $(\mathrm{pH}$ 3.0) containing $0.1 \mathrm{mM} \mathrm{Na} 2$ EDTA with a flow rate $0.6 \mathrm{~mL} \mathrm{~min}{ }^{-1}$. The modified electrode was kept at the potential $0.85 \mathrm{~V}$ vs. $\mathrm{Ag} / \mathrm{AgCl}$.

8) A capillary zone electrophoresis was employed for the analysis of glutathione using end-column amperometric detection on a gold/mercury amalgam microelectrode at a constant potential of 0.02-0.06 V vs. SCE [109]. In this procedure, deoxygenation wasn't need. The calibration plot was found to be linear over 1 to $100 \mu \mathrm{M}$ and the limit of detection was $0.63 \mu \mathrm{M}$. The effect of the concentration of the buffer, the high separation voltage across the capillary on the migration time and separation efficiency, the dependence of the injection conditions on the detection signal, the separation efficiency and the coulometric efficiency have been investigated. The method was applied to the determination of glutathione in human blood and erythrocytes.

9) Another analytical procedure exploits gold electrode for after HPLC column separation [110]. A $\mathrm{C}_{18}$ reverse phase column with a mobile phase of $5 \mathrm{mM}$ heptane sulphonic acid, $50 \mathrm{mM} \mathrm{KH}_{2} \mathrm{PO}_{4}$ in an $8 \%$ methanol-water mixture at $\mathrm{pH}$ 2.5 was used. A gold electrode was coated with mercury amalgam and polarised with a potential of $-0.100 \mathrm{~V}$. The limit of detection for GSH was in a rat liver extract 0.5 pmol.

10) A simultaneous down to femtomole determination of cysteine, reduced and oxidised glutathione, and phytochelatin in maize kernels using a HPLC with an electrochemical detection was used by Potesil et al. using hanging mercury drop electrode [111]. The mobile phase consisting from methanol and $0.05 \%(\mathrm{v} / \mathrm{v})$ TFA in ratio $97: 3(\% ; \mathrm{v} / \mathrm{v})$ was found to be the most suitable for the determination of thiol compounds. Optimal flow rate for the mobile phase was $0.18 \mathrm{~mL} \mathrm{~min}^{-1}$ and the column and detector temperatures were $35^{\circ} \mathrm{C}$. The most effective detection potentials were: $780 \mathrm{mV}$ for the GSSG and phytochelatins ${ }_{2}$, and $680 \mathrm{mV}$ for the determination of Cys and GSH. The optimised HPLC-ED 
method was able to determine the femtomole levels of tested compounds. The detection limits (basing on $3 \sigma$ ) of the studied thiol compounds were for cysteine 112.8 fmol, GSH 63.5 fmol, GSSG 112.2 fmol and phytochelatins $s_{2} 2.53$ pmol per injection $(5 \mu \mathrm{L})$.

11) The work-group of Hibbert has erected two papers [112,113] about the indirect amperometric detection of thiols on the tungsten-working electrode. They both relay on the detection of mercury(II) ions in the HPCL effluent by the three-electrode system. $\mathrm{Hg}^{2+}$ gives a sharp reduction current peak in the phosphate buffer ( $\mathrm{pH} \mathrm{3}$, reduction potential $-0.24 \mathrm{~V}$ vs. $\mathrm{Ag} / \mathrm{AgCl})$ when injected. When thiols are present, the reduction current of mercury will decrease due to complex formation between mercury ions and a thiol. A linear calibration curve for cysteine in the range of 0.25 to $100 \mu \mathrm{M}$ and 1.3 to $1000 \mathrm{ng}$ for glutathione, thiourea, albumin and DNA was found [113]. When using a $5 \mathrm{mM} \mathrm{Na}$-acetate buffer as an effluent $(\mathrm{pH} 4.7)$, the detection limit for cysteine, thiourea and glutathione was found in the range 0.41 to $1.65 \mu \mathrm{M}$; for albumin and DNA it was much less sensitive [112].

\section{b) Amperometric sensors used in bulk solution}

1) An amperometric biosensor for the determination of the reduced glutathione (GSH) in serum basing on the glutathione peroxidase immobilised onto a pyrolytic graphite working electrode using carbodiimide as an enzymatic condensing reagent was developed [114]. The concentration of reduced glutathione was monitored via the amperometrically monitored hydrogen peroxide electro-oxidation at the potential $0.65 \mathrm{~V}$ vs. SCE. The amperometric signal of GSH was linear in the range of $19-140 \mu \mathrm{M}$ in $0.1 \mathrm{M}$ phosphate buffer $(\mathrm{pH}=7.8)$.

2) Co-determination of lead and cysteine containing peptides in plant cells was presented by Vacek et al. [115]. Cysteine rich peptides were measured using differential pulse voltammetry and hanging mercury drop electrode (HMDE) in ammonia buffer containing $\mathrm{Co}^{3+}$ ions ("Brdicka reaction"). The linear response for GSH was found between 10 and $100 \mu \mathrm{M}$ measured in $1 \mathrm{~mL}$ of "Brdicka solution" ( $\left.1 \mathrm{M} \mathrm{NH}_{4} \mathrm{Cl}+1 \mathrm{M} \mathrm{NH}_{4} \mathrm{OH}+0.6 \mathrm{mM} \mathrm{Co}\left(\mathrm{NH}_{3}\right)_{6} \mathrm{Cl}_{3}, \mathrm{pH}=9.5\right)$.

3) An amperometric organically modified sol-gel glass encapsulating pyrroloquinone-modified electrode for the rapid and sensitive determination of organothiols was developed [116]. A potential of $-0.2 \mathrm{~V}$ vs. $\mathrm{Ag} / \mathrm{AgCl}$ (reference electrode) at the $\mathrm{pH}=3.5$ was applied for the detection of cysteine and glutathione with the detection limits $18 \mathrm{nM}$ and $36 \mathrm{nM}$ respectively. At $\mathrm{pH}=8.5$ the detection limits were much higher: $0.5 \mathrm{M}$ and $1 \mathrm{M}$, respectively. The electrode was stable within 7 days even stored at $4{ }^{\circ} \mathrm{C}$.

4) A mechanically immobilised nickel hexacyanoferrate onto paraffin impregnated graphite electrode as an amperometric sensor for thiols is constructed by Shankaran et al. [117]. This modified electrode is stable in the 0.1 $\mathrm{M} \mathrm{NaNO}_{3}$ aq. sol. in the $\mathrm{pH}$ range $2-8$ and between potentials 0.0 and $1.0 \mathrm{~V}$. The cysteine and the glutathione can be quantified in the concentration range 5.6 - $800 \mathrm{mM}$ and 5.4 - $600 \mathrm{mM}$, respectively. 
5) A carbon ceramic electrode modified with Nafion and $[\mathrm{Ru}(\mathrm{bpy})(\mathrm{tpy}) \mathrm{Cl}] \mathrm{PF}_{6}$ was developed by Salimi et al. [118]. The electro-oxidation of cysteine was successful in $\mathrm{pH}$ range $3-9$ supported by the anti fouling effect of Nafion film increasing the reproducibility of the results. The concentration calibration range and detection limits were for cysteine in the phosphate buffer $(\mathrm{pH} 5)$ applying the potential $0.6 \mathrm{~V}$ vs. $\mathrm{Ag} / \mathrm{AgCl}$ (in sat. $\mathrm{KCl}$ aq. sol) $0.1-100 \mu \mathrm{M}$ and $20 \mathrm{nM}$, respectively.

6) Using amperometric biosensors of glutathione based on the hydrogen peroxide or Clark type oxygen electrodes coupled with glutathione oxidase as an enzyme for the oxidation of glutathione, the obtained calibration curves were linear in the range $5-1000 \mu \mathrm{M}$ for hydrogen peroxide based probe and $10-200 \mu \mathrm{M}$ for Clark type probe [119]. The enzymes lifetime was found to be one month or at least 200 analyses. A phosphate buffer ( $\mathrm{pH}$ 6.5) was used as a media for analysis. Precision for hydrogen peroxide detection basing probe was $4.6 \%$ and $4.1 \%$ for Clark type probe.

7) An amperometric biosensor based on glutathione sulphydryl oxidase (GSHSOx) and osmium-polyvinylpyridine gel polymer (Os-gel-HRP) bi-layer film modified glassy carbon (GC) electrode was developed for the detection of glutathione (GSH) and glutathione disulphide (GSSG) [120]. The Os-gel-HRP was attached to glassy carbon (GC) electrode with a surface coverage of $7.1 \mu \mathrm{L}$ $\mathrm{cm}^{-2}$ to sense hydrogen peroxide based on horseradish peroxide (HRP) catalytic reaction mediated by osmium. GSH-SOx was immobilised at Os-gel-HRP coated $\mathrm{GC}$ electrode with an approximate surface coverage of $7 \mathrm{U} / \mathrm{cm}^{2}$ by cross-linking with the BAS-GSH-SOx. The sensor was polarised at $0.0 \mathrm{~V}$ vs. $\mathrm{Ag} / \mathrm{AgCl}(3 \mathrm{M}$ $\mathrm{KCl}$ ) in a flow system at a flow rate of $6 \mu \mathrm{L} \mathrm{min}^{-1}$. Linear response of $\mathrm{GSH}$ and GSSG was monitored in the concentration range from $1 \mu \mathrm{M}$ to $200 \mu \mathrm{M}$ and $2 \mu \mathrm{M}$ to $120 \mu \mathrm{M}$, respectively.

8) A carbon paste electrode (CPE) modified with $N, N$ '-thylenebis (salicylideneiminato)oxovanadium(IV) complex ([ $\left.\left.\mathrm{V}^{\mathrm{IV}} \mathrm{O}(\mathrm{Salen})\right]\right)$ was proposed as a sensor for cysteine [121]. The CPE with [VO(Salen)] has good electrochemical stability in a wide range of $\mathrm{pH}(4.0-10.0)$ and an ability to electro-oxidise cysteine at the potential 0.65Vversus SCE.

The electrode's response in $0.1 \mathrm{M} \mathrm{KCl}$ aq. solution $(\mathrm{pH} \mathrm{5.0)}$ ) is linear for cysteine in the concentration range from 0.24 to $2.3 \mathrm{mM}$. The detection limit was found $0.17 \mathrm{mM}(3 \sigma)$.

9) A selective flow-injection bi-amperometric determination of sulphurcontaining amino acids and structurally related compounds (like cysteine and methionine) is proposed [122]. This method bases on the reaction of the amino acid with chloramine- $T$. Then the excess of chloramine-T reacts with an acidic solution of iodide producing a stoichiometric amount of tri-iodide which is thereafter determined bi-amperometrically using two platinum electrodes polarised at $100 \mathrm{mV}$. The calibration graph is linear up to $10 \mu \mathrm{g} \mathrm{mL} \mathrm{m}^{-1}$ of cysteine and $30 \mu \mathrm{g} \mathrm{mL}^{-1}$ of methionine. The limit of detection is for cysteine 0.06 and for GSH $0.1 \mu \mathrm{g} \mathrm{ml}^{-1}$ and the repeatability (in a series of 70 injections of $5 \mu \mathrm{g} \mathrm{mL}^{-1}$ of cysteine or $15 \mu \mathrm{g} \mathrm{mL} \mathrm{m}^{-1}$ of methionine) was 1.1 and $0.7 \%$ for cysteine and methionine, respectively. 
10) The use of thin-film disposable gold working electrodes for cation chromatography-integrated pulsed amperometric detection of sulphur-containing amino acids is investigated by Cheng et al. [123]. The flow-through electrochemical cells were used. The effluent used was $20 \mathrm{mM} \mathrm{HClO}_{4}-0.15 \mathrm{M}$ $\mathrm{NaClO}_{4}$ in $5 \%(\mathrm{v} / \mathrm{v})$ acetonitrile aq. solution with a flow rate $0.25 \mathrm{~mL} \mathrm{~min}{ }^{-1}$. Compared to non-disposable working electrodes, the disposable working electrodes gave good results in the limit of detection, linearity of calibration and reproducibility as ordinary ones. When used with a new integrated pulse amperometric detection waveform, the disposable electrodes functioned reproducibly for 3 days. The limit of detection was $8 \mathrm{nM}$ and $16 \mathrm{nM}$, linear range $0.15-20 \mu \mathrm{M}$ and $0.30-20 \mu \mathrm{M}$ for cysteine and homocysteine, respectively.

11) Simultaneous, after isocratic cation exchange, integrated amperometric analysis of many important thioproteins and amino acids in plasma using gold electrodes was performed by Jandik et al. [124]. The effluent composition was $0.15 \mathrm{M}$ sodium perchlorate, $0.02 \mathrm{M}$ perchloric acid and 5\% acetonitrile aq. solution. Obtained results are for cysteine: the limit of detection (LOD) $14 \mathrm{nM}$, linear range (LR) $0.19-19 \mu \mathrm{M}$; for cysteinylglycine the LOD $46 \mathrm{nM}$, LR $0.19-$ $19 \mu \mathrm{M}$; glutathione (red) $47 \mathrm{nM}$, LR 0.19- $9.5 \mu \mathrm{M}$; homocysteine LOD $51 \mathrm{nM}$, LR 0.95 - $19 \mu \mathrm{M}$; methionine LOD $51 \mathrm{nM}$, LR $0.95-19 \mu \mathrm{M}$; glutathione (ox) LOD $56 \mathrm{nM}$, LR 0.95 - $19 \mu \mathrm{M}$; cystine LOD $40 \mathrm{nM}$, LR $0.95-19 \mu \mathrm{M}$; cystathionine $91 \mathrm{nM}$, LR $0.95-19 \mu \mathrm{M}$.

Conclusion for the review section of the electrochemical methods for the determination of the thiol-containing peptides

From the previous list of the electroanalytical methods, it is obvious that the amperometric techniques have higher sensitivity than the voltammetric ones, having detection limits in the range of $\mathrm{nM}$ (compared to $\mu \mathrm{M}$ for voltammetric ones). The separation of the amperometric techniques to "after-column" and "in bulk solutions", is artificial, but gives overview about sensors already applied in "after-column" detection. Therefore, when having complicated natural samples with a high content of surface active organic substances, the after-column detection methods should be preferred.

\section{References}

1. http://www.mathcell.ru/show_topic_en.php?file=end_sh

2. J. Rutishauser and M. Spiess, Swiss Med WKLY 132 (2002) 211.

3. C. Hwang, A.J. Sinskey, H.F. Lodish, Science 257 (1992) 1496.

4. J. Qin, Y. Yang, A. Velyvis and A. Gronenborn, Antioxidants \& Redox Signaling 2 (2000) 827.

5. S.J. Bannister, K.D. Wittrup, Biotechn. and Bioeng. 68 (2000) 389.

6. C. Hwang, A.J. Sinskey, H.F. Lodish, Science 257 (1992) 1496.

7. S. Carelli, A. Ceriotti, A. Cabibbo, G. Fassina, M. Ruvo and R. Sitia, Science 277 (1997) 1681. 
8. A. Holmgren, Antioxidants \& Redox Signaling 2 (2000) 811.

9. J.W. Cuozzo and C.A. Kaiser, Nature Cell Biology 1 (1999) 130.

10. F. Åslund, K.D. Berndt and A. Holmgren, J. Biol. Chem. 272 (1997) 30780.

11. M. Wunderlich and R. Glockshuber, Protein Science 2 (1993) 717.

12. N.J. Bulleid and R.B. Freedman, Nature 335 (1988) 649.

13. M.A. Kaderbhai and B.M. Austen, Eur. J. Biochem. 153 (1985) 167.

14. G. Scheele and R. Jacoby, J. Biol. Chem. 257 (1982) 12277.

15. G. Scheele and R. Jacoby, J. Biol. Chem. 258 (1983) 2005.

16. J. Martensson, J.C.K. Lai, A. Meister, Proc. Natl. Acad. Sci. U.S.A. 87 (1990) 7185.

17. N. Hayashib, N. Satob, T. Kamadab and K. Tagawa, Biochem. Biophys. Res. Commun. 167 (1990) 367.

18. R. Bass, L.W. Ruddock, P. Klappa and R.B. Freedman, J. Biol. Chem. 279 (2004) 5257.

19. L. Abello, A. Ensuque, G. Lapluye, J. Chim. Phys. 73 (1976) 268.

20. T.V. DeCollo and W.J. Lees, J. Org. Chem. 66 (2001) 4244.

21. J.H. Bushweller, F. Åslund, K. Wütrich F. Wütrich and A. Holmgren, Biochem. 31 (1992) 9288.

22. S.A. Gravina and J.J. Mieyal, Biochem. 32 (1993) 3368.

23. Y. Yang, S. Jiao, R.S. Nanduri, D.W. Starke, J. Mieyal and J. Qin, Biochem. 37 (1998) 17145.

24. N. Reckenfelderbäumer and R.L. Krauth-Siegel, J. Biol. Chem. 20 (2002) 17548.

25. A. Bonsignore, I. Lorenzoni, R. Cancedda, L. Silengo, D. Dina and A. De Flora, Ital. J. Biochem. 17 (1968) 346.

26. L.V. Eggleston and H.A. Krebs, Biochem. J. 138 (1974) 425.

27. L.K. Moran, J.M.C. Gutteridge and G.J. Quinlan, Current Medicinal Chemistry 8 (2001) 763.

28. P.C. Jocelyn, Eur. J. Biochem. 2 (1967) 327.

29. K. Linke and U. Jakob, Antioxidants \& Redox Signaling 5 (2003) 425.

30. R. Boggess, J. Absher, S. Morelen, L.T. Taylor, J.W. Hughes, Inorg. Chem. 22 (1983) 1273.

31. A. Claiborne, J.I. Yeh, T.C. Mallet, J. Luba, E.J. Crane, V. Charrier and D. Parsonage, Biochem. 38 (1999) 15407.

32. J.A. Thomas and R. Mallis, Cellular Implications of Redox Signalling, Imperial College Press, London, 2003, 141.

33. J. Köhrle, R. Brigelius-Flohé, A. Böck, R. Gärtner, O. Meyer and L. Flohé, Biol. Chem. 381 (2000) 849.

34. T. Tamura, T.C. Stadtman, Proc. Natl. Acad. Sci. U.S.A. 93 (1996) 1006.

35. L. Zhong, E.S. Arner and A. Holmgren, Proc. Natl. Acad. Sci. U.S.A. 97 (2000) 5854.

36. C. Buettner, J.W. Harney and M.J. Berry, J. Biol. Chem. 274 (1999) 21598.

37. S.R. Lee, S. Bar-Noy, J. Kwon, R.L. Levine, T.C. Stadtman and S.G. Rhee, Proc. Natl. Acad. Sci. U.S.A. 97 (2000) 2521.

38. A. Nishiyama, H. Masutani, H. Nakamura, Y. Nishinaka and J. Yodoi, IUBMB Life 52 (2001) 29. 
39. A. Holmgren, Ann. Rev. Biochem. 54 (1985) 237.

40. T.D. Lockwood, Antioxidants \& Redox Signaling 2 (2000) 851.

41. H. Masutani and J. Yodoi, Methods Enzymol. 347 (2002) 279.

42. P.T. Chivers, K.E. Prehoda and R.T. Raines, Biochem. 36 (1997) 4061.

43. A. Holmgren, Eur. J. Biochem. 6 (1968) 475.

44. G. Krause and A. Holmgrem, J. Biol. Chem. 266 (1991) 4056.

45. T.-Y. Lin and P.S. Kim, Biochem. 28 (1989) 5282.

46. A. Zapun, J.C.A. Bardwell and T.E. Creighton, Biochem. 32 (1993) 5083.

47. E.A. Kersteen and R.T. Raines, Antioxidants \& Redox Signaling 5 (2003) 413.

48. M. Wunderlich and R. Glockshuber, Protein Science 2 (1993) 717.

49. J. Yarimizu, H. Nakamura, J. Yodoi and K. Takahashi, Antioxidants \& Redox Signaling 2 (2000) 643.

50. T. Tamura, T.C. Stadtman, Proc. Natl. Acad. Sci. U.S.A. 93 (1996) 1006.

51. L. Zhong, E.S. Arner and A. Holmgren, Proc. Natl. Acad. Sci. U.S.A. 97 (2000) 5854.

52. C. Buettner, J.W. Harney and M.J. Berry, J. Biol. Chem. 274 (1999) 21598.

53. L. Flohé, Signal Transduction by Reactive Oxygen, Kluwer Academic Publishers, Dordrecht, 2003, pp. 15-32.

54. M. Birringer, S. Pilawa and L. Flohé, Nat. Prot. Rep. 19 (2002) 693.

55. M. Bjørnstedt, S. Kumar and A. Holmgren, J. Biol. Chem. 267 (1992) 8030.

56. J. Kim and S.P. Mayfield, Science 278 (1997) 1954.

57. A. Hiniker and J.C.A. Bardwell, Trends in Biochem. Sci. 29 (2004) 516.

58. K.J. Woycechowsky and R.T. Raines, Current Opinion in Chemical Biology 4 (2000) 533.

59. D.M. Ferrari and H.-D. Söling, Biochem. J. 339 (1999) 1.

60. M. van Lith, N. Hartigan, J. Hatch and A.M. Benham, J. Biol. Chem. 280 (2005) 1376.

61. M.C.A. Laboissiere, S.L. Sturley and R.T. Raines, J. Biol. Chem. 270 (1995) 28006.

62. H.C. Hawkins and R.B. Freedman, Biochem. J. 275 (1991) 335.

63. M.-L. LaMantia and W.J. Lennarz, Cell 74 (1993) 899.

64. H.C. Hawkins, M. de Nardi and R.B. Freedman, Biochem. J. 275 (1991) 341.

65. B. Kleizen and I. Braakman, Current Opinion in Cell Biology 16 (2004) 343.

66. M. Bader, J.R. Winther and J.C.A. Bardwell, Nature Cell Biol. 1 (1999) E57.

67. A.R. Frand and C.A. Kaiser, Mol. Cell 1 (1998) 161.

68. R.B. Freedman, A.D. Dunn and L.W. Ruddock, Curr. Biol. 8 (1998) R468.

69. C.S. Sevier, J.W. Couzzo, A. Vala, F. Åslund and C.A. Kaiser, Nat. Cell Biol. 3 (2001) 874.

70. J.C.A. Bardwell, Devel. Cell 3 (2002) 758.

71. L. Ellgaard, Biochem. Soc. Trans. 32 (2004) 663.

72. A.R. Frand and C.A. Kaiser, Mol. Biol. Cell 11 (2000) 2833.

73. S. Raje and C. Thorpe, Biochem. 42 (2003) 4560. 
74. E. Gross, C.S. Sevier, A. Vala, C.A. Kaiser and D. Fass, Nat. Struct. Biol. 9 (2002) 61.

75. E. Gross, D.B. Kastner, C.A. Kaiser and D. Fass, Cell 117 (2004) 601.

76. R. Krupp, C. Chan and D. Missiakas, J. Biol. Chem. 276 (2001) 3696.

77. H. Nakamoto and J.C.A. Bardwell, Biochim. Biophys. Acta 1694 (2004) 111.

78. E. Mössner, M. Huber-Wunderlich, A. Rietsch, J. Beckwith, R. Glockshuber and F. Åslund, J. Biol. Chem. 274 (1999) 25254.

79. M. Bader, W. Muse, D.P. Ballou, C. Gassner and J.C.A. Bardwell, Cell 98 (1999) 217.

80. G.C. Wagner, R.J. Kassner, M.D. Kamen, Proc. Natl. Acad. Sci. U.S.A. 71 (1974) 253.

81. E.A. Kersteen and R.T. Raines, Antioxidants \& Redox Signaling 5 (2003) 413.

82. R.P. Szajewski and G.M. Whitesides, J. Am. Chem. Soc. 102 (1980) 2011.

83. S. Yamaguchi, T. Tsukamoto and M. Senda, Nippon Kagaku Kaishi 5 (1980) 722. (Written in Japanese, abstr. in Eng.)

84. K. Brocklehurst, T. Stuchbury, J.P.G. Malthouse, Biochem. J. 183 (1979) 233.

85. J. Winter, H. Lilie and R. Rudolph, FEMS Microbiology Letters 213 (2002) 225.

86. K.J. Woycechowsky, K.D. Wittrup and R.T. Raines, Chem. \& Biol. 6 (1999) 871.

87. K.J. Woycechowsky, B.A. Hook and R.T. Raines, Biotechnol. Prog. 19 (2003) 1307.

88. J.A. Burns, J.C. Butler, J. Moran, G.M. Whitesides, J. Org. Chem. 56 (1991) 2648.

89. J.C. Han and G.Y. Han, Anal. Biochem. 220 (1994) 5.

90. A. Christine, L. Gall, C.M.G. Van Den Berg, Deep-Sea Res. 1 (1998) 1903.

91. A.-C. Le Gall, C.M.G. Van den Berg, Analyst 118 (1993) 1411.

92. R.R. Moore, C.E. Banks and R.G. Compton, Analyst 129 (2004) 755.

93. J.B. Raoof, R. Ojani and M. Kolbadinezhad, Bull. Chem. Soc. Jpn. 78 (2005) 818.

94. S. Fei, J. Chen, S. Yao, G. Deng, D. He and Y. Kuang, Anal. Biochem. 339 (2005) 29.

95. Z. Dursun, I. Sahbaz, F.N. Ertas and G. Nisli, Turkish J. Chem. 4 (2003) 513.

96. P.C. White, N.S. Lawrence, J. Davis, R.G. Compton, Anal. Chim. Acta 447 (2001) 1 .

97. P. White, N.S. Lawrence, Y.C. Tsai, J. Davis and R.G. Compton, Microchim. Acta 137 (2001) 87.

98. N.S. Lawrence, J. Davis and R.G. Compton, Talanta 53 (2001) 1089.

99. E.H. Seymour, S.J. Wilkins, N.S. Lawrence and R.G. Compton, Anal. Lett., 35 (2002) 1387.

100. G. Hignett, S. Threlfell, A.J. Wain, N.S. Lawrence, S.J. Wilkins, J. Davis, R.G. Compton and M.F. Cardosi, Analyst 126 (2001) 353. 
101. C. Terashima, T.N. Rao, B.V. Sarada and A. Fujishima, Chem. Lett. 32 (2003) 136.

102. O. Chailapakul, W. Siangproh, B.V. Sarada, C. Terashima, T.N. Rao, D. A. Tryk and A. Fujishima, Analyst 127 (2002) 1164.

103. J. Zhou, T.J. O'Shea and S.M. Lunte, J. Chrom. A 680 (1994) 271.

104. T.J. O'Shea and S.M. Lunte, Anal. Chem. 65 (1993) 247.

105. J.A. Cox and E. Dabek-Zlotorznska, J. Chrom. A 543 (1991) 226.

106. X.-N. Cao, J.-H. Li, H.-H. Xu, L. Lin, Y.Z. Xian, K. Yamamoto and L.-T. Jin, Biomed. Chrom. 18 (2004) 564.

107. P.J. Vandeberg and D.C. Johnson, Anal. Chim. Acta 290 (1994) 317.

108. F. Xu, L. Wang, M. Gao and L. Jin, Anal. Bioanal. Chem. 372 (2002) 791.

109. W. Jin and Y. Wang, Anal. Chim. Acta 343 (1997) 231.

110. C.B. Jensen, S.J. Grossman and D.J. Jollow, Adv. Exp. Med. 197 (1986) 407.

111. D. Potesil, J. Petrlova, V. Adam, J. Vacek, B. Klejdus, J. Zahnalek, L. Trnkova, L. Havel and R. Kizek, J. Chrom A 1084 (2005) 134.

112. P.W. Alexander, A. Hidayat and D.B. Hibbert, Electroanalysis 7 (1995) 290.

113. A. Hidayat, D.B. Hibbert and P.W. Alexander, Electroanalysis 8 (1996) 468.

114. L. Rover Jr., L.T. Kuboto and N.F. Höehr, Clin. Chim Acta 308 (2001) 55.

115. J. Vacek, J. Petrek, R. Kizek, L. Havel, B. Klejdus, L. Trnková and F. Jelen, Bioelectrochem. 63 (2004) 347.

116. K.A. Joshi, P.C. Pandley, W. Chen and A. Mulchandani, Electroanalysis 16 (2004) 1938.

117. R.D. Shankaran and S.S. Narayanan, Bull. Electrochem. 17 (2001) 277.

118. A. Salimi, R. Hallaj and M.K. Amini, Anal. Chim. Acta 534 (2005) 335.

119. D. Compagnone, G. Federici, L. Scarciglia and G. Palleschi, Biosensors and Bioelectronics 8 (1993) 257.

120. L. Mao and K. Yamamoto, Electroanalysis 12 (2000) 577.

121. M.F.S. Teixeira, E.R. Dockal and E.T.G. Cavalheiro, Sensors and Actuators $B 106(2005) 619$.

122. M.C. Icardo, O.A. Estrela, M. Sajewicz, J.V.G. Mateo and J.M. Calatayud, Anal. Chim. Acta 438 (2001) 281.

123. J. Cheng, P. Jandik and N. Avdalovic, J. Chrom. A 997 (2003) 73.

124. P. Jandik, J. Cheng, J. Evrovski and N. Avdalovic, J. Chrom. B 759 (2001) 145. 